\title{
The Diversion in Law Enforcement of Criminal Action of Children in the Judicial System of Children
}

\author{
Danang Sucahyo ${ }^{*}$ and Aryani Witasari ${ }^{* *}$ \\ ${ }^{*}$ Student of Master of Law, Faculty of Law, Universitas Islam Sultan Agung \\ Semarang and Head of Sub-Section for Legal Considerations at the Wonosobo \\ District Attorney, E-mail: danang.sucahyo@kejaksaan.go.id \\ ${ }^{* *}$ Lecture of Faculty of Law, Universitas Islam Sultan Agung Semarang
}

\begin{abstract}
Handling of crimes committed by children is carried out through the juvenile criminal justice system, as regulated in Act No. 11 of 2012. In Act No. 11 of 2012, the settlement of criminal cases of children is carried out by means of a diversion mechanism. This study aims to determine and examine diversion in law enforcement of child criminal acts in the juvenile criminal justice system. This study uses a normative juridical approach, which is descriptive analysis. The data used is secondary data obtained through library research, which is then analyzed qualitatively. The result of this research is that diversion is a persuasive action or an approach that aims to invite people to obey and enforce the law while still considering the sense of justice as a top priority in addition to providing opportunities for perpetrators to improve themselves. Diversion in the juvenile criminal justice process is regulated in Article 8 of Act No. 11 of 2012, which is carried out through deliberations involving the child and his/her parents/guardians, the victim and/or their parents/guardians, social advisers, and professional social workers. The diversion provision is applied to criminal offenses that carry a sentence of less than seven years and do not constitute a repetition of the crime. Diversion in the juvenile criminal justice process is regulated in Article 8 of Act No. 11 of 2012, which is carried out through deliberations involving the child and his/her parents/guardians, the victim and/or their parents/guardians, social advisers, and professional social workers. The diversion provision is applied to criminal offenses that carry a sentence of less than seven years and do not constitute a repetition of the crime. Diversion in the juvenile criminal justice process is regulated in Article 8 of Act No. 11 of 2012, which is carried out through deliberations involving the child and his/her parents/guardians, the victim and/or their parents/guardians, social advisers, and professional social workers. The diversion provision is applied to criminal offenses that carry a sentence of less than seven years and do not constitute a repetition of the crime.

Keywords: Diversion; Law Enforcement; Crime; Children; Criminal Justice System.
\end{abstract}

\section{Introduction}

Indonesia is a rule of law country. According to Aristotle, a rule of law is a state that stands on the law that guarantees justice to its citizens. Good law is law that comes from a sense of justice in the community and those who rule in the state are just thoughts, while the ruler is only the holder of law and balance. ${ }^{1}$

\footnotetext{
${ }^{1}$ Sinamo, Nomensen. (2014). Hukum Tata Negara Indonesia, Third Edition. Jakarta: Permata Aksara. p. 36.
} 
The law serves as a guide for everyone to behave, considering that society is a game with preconceived rules and in turn allows clarity about what can be expected from each action taken by each person. ${ }^{2}$

To create a rule of law, a legal instrument is needed to regulate balance and justice in all areas of life and livelihood of the people through statutory regulations. In general, the community recognizes law as rules, norms, guidelines, behavior, or statutory regulations which, if violated, will be subject to sanctions. This understanding is very easy for the public to understand, because for people who are wrong or violating the rules they must be punished, ${ }^{3}$ no matter the person who violates the law is an adult or a child, but especially for children must get different treatment.

Crimes or criminal acts that occur in society today, are not only committed by adults, but also by children, where the crime was originally from the child's delinquency which caused disturbances in the community environment, but has also harmed and caused the downfall. victims, so that the child's delinquency could no longer be tolerated by society. As a form of legal protection for victims, of course the rights or interests of victims must be restored. ${ }^{4}$ Protecting the entire Indonesian nation is a task that must be carried out by the government whose obligations are the basic rights of citizens without exception. ${ }^{5}$

Children who commit crimes tend not to understand what they have done, and do not understand the legal consequences of their actions, because from a psychological perspective, children are still unstable. According to Sugiri, as long as the growth and development process is still in progress, the child is still a child, and only becomes an adult when the development and growth process is complete, so the age limit for children is the same as the beginning of adulthood, which is 18 (eight twelve) years for women and 21 (twenty) years for men. ${ }^{6}$

Any crime that occurs in society must be tackled and eradicated. Apart from overcoming criminal acts, as a rule of law, the law must be enforced so that a society that is safe, peaceful, lawful, and all forms of criminal acts can be minimized and even eradicated to the roots.

Children who commit crimes must face the law to be accountable for their actions. Children who are confronted by the law according to the provisions of Article 1 point 2 of Act No. 11 of 2012 concerning the Criminal Justice System for Children are children who are in conflict with the law, children who are victims of crime, and children who are witnesses of criminal acts. The child must receive legal protection.

\footnotetext{
${ }^{2}$ Setiadi, Edi and Rena Yulia. (2010). Hukum Pidana Ekonomi. Yogyakarta: Graha IImu. p. 1.

${ }^{3}$ Arsyad, Jawade Hafidz and Dian Karisma. (2018). Sentralisasi Birokrasi Pengadaan Barang \& Jasa Pemerintah. Jakarta: Sinar Grafika. p. 63.

${ }^{4}$ Hengki Irawan, Sri Endah Wahyuningsih, and Jawade Hafidz, December 2019, Legal Protection For Victims Of Traffic Violations That Lead To Death (Case Study On Police Traffic of Rembang), Jurnal Daulat Hukum, Vol. 2 No. 4, Faculty of Law, Universitas Islam Sultan Agung, Semarang, url: http://jurnal.unissula.ac.id/index.php/RH/article/view/8349/3869, p. 490.

${ }^{5}$ Farhan Munirus Su'aidi and Abdullah Arief Cholil, December 2019, Law Protection on Wife Whose The Claims Fall Due To Husband Refuse His Recompensation On Implementing Of Divorce Pledge, Jurnal Daulat Hukum, Vol. 2 No. 4, Faculty of Law, Universitas Islam Sultan Agung, Semarang, url: http://jurnal.unissula.ac.id/index.php/RH/article/view/8367/3897, p. 548.

${ }^{6}$ Gultom, Maidin. (2010). Perlindungan Hukum Terhadap Anak, Second Edition. Bandung: Refika Aditama. p. 32.
} 
Criminal law today must be adapted to the nature and style of crimes that arise in accordance with the times and developments in society. On the other hand, if the criminal law and its law enforcement do not conform to the nature and features of the ever-evolving crimes, then the criminal law will not be able to fulfill its function, namely to provide protection for the sake of creating the welfare of society. ${ }^{7}$

As is the case in handling child criminal cases, of course it is different from dealing with perpetrators of criminal acts committed by adults. The justice system that must be passed by children who are dealing with the law, namely the justice system that is specifically for children. The juvenile justice system according to Article 1 number 1 of Act No. 11 of 2012 is the entire process of solving cases of children in conflict with the law, from the investigation stage to the guidance stage after serving a crime.

In order to tackle criminal acts committed by children, Act No. 11 of 2012 concerning the Criminal Justice System for Children as a reference for resolving criminal cases committed by children must be enforced. This is not to torture or make the child suffer, but as an effort to hold the child responsible for his actions towards the victim, and to improve the child's behavior for the child's future.

Law enforcement has a strategic position. Law enforcement in the macro sense covers all aspects of community life, as a nation and a state, whereas in the micro sense law enforcement is limited in litigation processes in court, both in civil cases, state administration and in criminal cases including processes of investigation, investigation, prosecution. (examination before the court) to the implementation of court decisions that have permanent legal force. ${ }^{8}$

Law enforcement against criminal offenses committed by children refers to Act No. 11 of 2012, namely that efforts to resolve child crimes outside the penal route (nonlitigation) are mandatory, using a diversion mechanism.

The main principle of the implementation of diversion, namely persuasive action or approaching and providing opportunities for actors to change. Officials must demonstrate the importance of obedience to the law in a persuasive approach and avoid arrest using force and coercion to carry out diversion. The use of force will lead to compulsion as a result of law enforcement. ${ }^{9}$

Diversion is an effort made by the government and law enforcers with the aim of inviting the public to obey and uphold the law while still considering the sense of justice as a top priority in addition to providing opportunities for perpetrators to improve themselves. Diversion does not aim to ignore law and justice, but diversion is a new way of upholding justice in society.

The purpose of this research is to find out and examine the diversion in law enforcement of child crimes in the juvenile criminal justice system.

\footnotetext{
${ }^{7}$ Setiadi, Edi and Kristian. (2017). Peradilan Pidana Terpadu Dan Sistem Penegakan Hukum Di Indonesia, First Edition. Jakarta: Kencana Prenada Media Group. p. 3.

8 Effendy, Marwan. (2012). Diskresi, Penemuan Hukum, Korporasi \& Tax Amnesty Dalam Penegakan Hukum, First Edition. Jakarta: Referensi, p. 2.

${ }^{9}$ Marlina. (2012). Peradilan Pidana Anak Di Indonesia, Pengembangan Konsep Diversi dan Restorative Justice, Second Edition. Bandung: Refika Aditama. p. 22.
} 


\section{Research methods}

The type of research used in writing this legal journal is normative juridical. Normative juridical research is research that is focused on examining the application of the rules or norms in positive law, ${ }^{10}$ which in this case relates to diversion in law enforcement of child criminal acts in the juvenile criminal justice system. This research is descriptive analysis, because the researcher wishes to describe or explain the subject and object of the research, which then analyzes and finally draws conclusions from the research results. ${ }^{11}$ The data used in this research is secondary data. Secondary data is data obtained from library materials through library research, and this data is also obtained from agencies/institutions related to the purpose of this research. ${ }^{12}$ According to the data that has been obtained during conducting research by reading library books, then analyzed. The analysis used in this research is qualitative data analysis.

\section{Results and Discussion}

Suparno Paul argued that the status and condition of Indonesian children was a paradox. Ideally, children are the heirs and continuation of the future of the nation. In real terms, the situation for Indonesian children is still and continues to worsen. The world of children should be colored by the activities of playing, learning, and developing their interests and talents for the future, the reality is colored with dark and sad data, ${ }^{13}$ such as a crime or criminal act perpetrated by children.

Crime of children and youth is already a big part of crime, moreover most adult criminals generally have committed crimes since childhood. The prevention of the crime of children will also have a good effect on the prevention of adult crime. ${ }^{14}$

Criminal acts, both committed by children and by adults, have legal consequences for the perpetrators, namely the perpetrators of criminal acts must be brought to court to account for their actions, so that justice can be created for both the victim and the community. Law enforcement efforts must be carried out in accordance with the provisions of the applicable laws, and based on a sense of community justice so that it can provide benefits to all parties.

Law enforcement and justice in a fair or just legal process is the enforcement guaranteed by the 1945 Constitution of the Republic of Indonesia which provides protection and benefits for every citizen in the context of upholding the supremacy of the constitution as the basic law of the state. Therefore, the series of principles of a fair and complete legal process, good and perfect, the 1945 Constitution of the Republic of

\footnotetext{
${ }^{10}$ Ibrahim, Jhonny. (2011). Teori dan Metodologi Penelitian Hukum Normatif. Malang: Bayumedia. p. 295.

11 Mukti Fajar ND and Yulianto Achmad. (2010). Dualisme Penelitian Hukum Normatif dan Empiris. Yogyakarta: Pustaka Pelajar. p. 183.

12 Soeratno and Lincolin Arsyad. (2003). Metodologi Penelitian Untuk Ekonomi Dan Bisnis. Yogyakarta: UPP AMP YKPN. p. 173.

13 Aan Hardiansyah, Akhmad Khisni, and Jawade Hafidz, March 2018, Violence in the Teaching and Learning Process Viewed from the Perspective of Criminal Law and Act No. 14 of 2005 Regarding Teachers and Lecturers, Jurnal Daulat Hukum, Vol. 1. No. 1, Faculty of Law, Universitas Islam Sultan Agung, Semarang, url: http: //jurnal.unissula. ac.id/index.php/RH/article/view/2622/1972, p. 89.

${ }^{14}$ Wagiati Soetedjo and Melani. (2017). Hukum Pidana Anak, Fifth Edition. Bandung: Refika Aditama. p. 143.
} 
Indonesia and the laws and regulations do not mean much to any citizen or society, if they are not enforced or implemented properly and fair, and will create a bad image for Indonesia as a democratic rule of law (rechtstaat en democratische). ${ }^{15}$

The ultimate goal of criminal law enforcement is to tackle crime by punishing everyone who is guilty. In this context, every criminal justice process must be based on a due process of law. Because as a "truth determination" process that confronts a suspect in an examination, where the legal apparatus has a large legal authority, the criminal justice process must be carried out according to the principles of a fair legal process. It is not only the apparatus' version of truth that must be considered, but also the truth of the accused's version. In this case, throughout the judicial process, the accused must be given the opportunity to be heard, to defend himself, to present evidence in his favor, and his right to be tried by a fair and impartial court is respected. ${ }^{16}$

As stated that law enforcement is to tackle criminal acts and impose fair criminal sanctions for the perpetrators. Criminal is a sentence imposed on a person who is legally and convincingly proven to have committed a criminal act, and this punishment is imposed or stipulated by a court ruling which investigates and resolves the case in question. $^{17}$

Handling criminal acts committed by children through the general justice system will have a bad impact on the child, so that children who are in conflict with the law must be placed in special courts to settle their cases, namely juvenile justice, as is the provisions in the Act No. 11 of 2012.

Children must be given different treatment, between the perpetrator and the victim of a criminal act. This needs to be done because children are the next generation of the nation who should have received protection, such as children who are involved in a crime and cause children to conflict with the law, children who are in conflict with the law or children in special situations. ${ }^{18}$

Mohammad Taufik Makarao stated that one of the efforts to prevent and overcome children in conflict with the law today is through the implementation of the juvenile criminal justice system. To carry out guidance and provide protection for children, support is needed, both in terms of institutions and legal instruments that are more solid and adequate. Therefore, the provisions regarding court administration for children need to be made specifically. ${ }^{19}$

The emergence of a bad influence on the criminal justice process on children, can be caused by the influence of the provisions of the law and from law enforcement factors,

\footnotetext{
${ }^{15}$ Latif, Abdul. (2014). Hukum Administrasi Dalam Praktik Tindak Pidana Korupsi, First Edition. Jakarta: Kencana Prenada Media. p. 162-163

${ }^{16}$ Parera, Theodorus Yosep. (2016). Advokat dan Penegakan Hukum, First Edition. Yogyakarta: Genta Press. p. 19-20.

${ }^{17}$ Setiady, Tolib. (2010). Pokok-Pokok Hukum Panitensier Indonesia. Bandung: Alfabeta, p. 209.

${ }^{18}$ Rendy Surya Aditama, Umar Ma'ruf, and Munsharif Abdul Chalim, March 2018, Criminal Law Policy Against Children as Perpetrators of Psychotropic Crimes at the Magelang Resort Police, Jurnal Daulat Hukum, Vol. 1. No. 1, Faculty of Law, Universitas Islam Sultan Agung, Semarang, url: http://jurnal.unissula.ac.id/index.php/RH/article/view/2625/1974, p. 119.

${ }_{19}$ Fiska Ananda, March 2018, Application of Diversion as Efforts to Protect the Law Against Child Perpetrators of Crime, Jurnal Daulat Hukum, Vol. 1. No. 1, Faculty of Law, Universitas Islam Sultan Agung, Semarang, url: http://jurnal.unissula.ac.id/index.php/RH/article/view / 2566/1923, p. 78.
} 
as well as factors from the culture of the community in general. Factors from the Juvenile Court Law itself cause stigma, namely the provision that for child prisoners there is an obligation to be fostered and admitted to a correctional facility. The bad effects of the juvenile criminal justice process can be in the form of: ${ }^{20}$

- Trauma due to the treatment of law enforcers at every stage;

- Stigma/evil stamp on the perpetrator so that the child is always worried about doing evil;

- Child expelled from school.

The process of criminal justice against children in practice tends to leave a stigma on the child. This stigmatization process takes place at the level of investigation, prosecution, trials in court to the place of guidance. The bad effects of the juvenile criminal justice system on children at each stage are as follows: ${ }^{21}$

- Pre trial stage;

In the pre-trial stage, which are sources of pressure on the child and adversely affect the child, are in the form of fear, anxiety, sleep disturbances, appetite disorders or mental disorders, namely:

- Medical check up;

- Unsympathetic, repeated and harsh, and heartless questions by the examining officer;

- Must retell unpleasant experiences or events and reconstruct;

- Interviews and media coverage;

- Waiting for trial;

- Pending trial proceedings;

- Separation from family or residence.

- The trial stage;

The stage of the trial that puts pressure on the child, so that the child is anxious, crying, embarrassed, depressed, thinking disorders and others, namely:

- Waiting in the courtroom;

- Lack of knowledge about the ongoing process;

- Courtroom layout;

- Dealing with witnesses and victims;

- Speaking before court officials;

- The examination process in a trial.

- The post-trial stage.

The post-trial stage that puts pressure on the child, which causes it to adversely affect the child, namely:

- Judge's decision;

- No follow-up;

- Continuous stigma;

- Guilty feeling;

- Anger from the family.

\footnotetext{
${ }^{20}$ Wahyudi, Setya. (2011). Implementasi Ide Diversi Dalam Pembaruan Sistem Peradilan Pidana Anak Di Indonesia, First Edition. Yogyakarta: Genta Publishing. p. 140-141.

${ }^{21}$ Ibid.
} 
These bad effects can be avoided if diversion (diversion) is carried out. With diversion, children are avoided from formal justice processes, and there is no recording of crimes against these children. Diversion can be used as a means to improve child perpetrators of crime, or to prevent, suspend or reduce punishment against children based on humanitarian feelings.

The word diversion comes from the English "diversion". Diversion is a term of diversion, because it is based on the General Guidelines for Enhanced Indonesian Language Spelling and General Guidelines for the Formation of Terms, the suffix -si adjustments, tion become -si. Therefore, the word diversion in Indonesia has become a diversion. ${ }^{22}$ Etymologically, the word diversion has the equivalent meaning of the same word "divert", in English which means: "the act of changing the direction that somebody or something is following, or what something is used for" (meaning: an action for change the course that something is taking or change the purpose of a person, or change the use that is usually used). ${ }^{23}$

According to M. Nasir Jamil, the definition of diversion is a diversion of the settlement of cases of children suspected of committing certain crimes from the formal criminal process to peaceful settlement between the suspect/defendant/perpetrator of a criminal act and the victim facilitated by the family and/or the community, the Community Advisor. Child, police, prosecutor, or judge. ${ }^{24}$ Meanwhile, the definition of diversion, according to Marlina, is a policy implemented to prevent perpetrators from the formal criminal justice system from providing protection and rehabilitation to perpetrators in an effort to prevent children from becoming adult criminals. ${ }^{25}$

Diversion is a means of criminal policy (crime prevention policy, criminal policy) because the aim of conducting diversion programs is to prevent further child crimes from occurring in the future. Prevention of child crime is carried out in the form of programs, such as community supervision, restution, compensation, fine, counseling, or activities that involve family parties (family intervention). It is hoped that all these diversion programs will be useful to prevent further child crimes. ${ }^{26}$

The purpose of diversion is to try to restore remedy to a problem, not a retaliation that has been known in criminal law. ${ }^{27}$

The main aim of diversion is to avoid stigma in children. Diversion is able to avoid stigma because the police do not record data as delinquent children, and the public prosecutor does not carry out prosecutions, does not make indictments, and then prosecutors do not delegate to court. If the case has entered the court, the judge implements diversion by selecting cases that are continued with examination or

\footnotetext{
22 Ibid. p. 56.

23 Sinaga, Dahlan. (2017). Penegakan Hukum Dengan Pendekatan Diversi (Perspektif Teori Keadilan Bermartabat), First Edition. Yogyakarta: Nusa Media. p.25

${ }^{23}$ Ibid.

24 Jamil, M. Nasir. (2013). Anak Bukan Untuk Dihukum, Catatan Pembahasan Undang-Undang Sistem Peradilan Pidana Anak (UU SPPA). Jakarta: Sinar Grafika. p. 137.

${ }^{25}$ Marlina, loc.cit., p. 22.

${ }^{26}$ Setya Wahyudi, op.cit., p. 139-140.

${ }^{27}$ M. Nasir Jamil, op.cit., P. 138.
} 
terminated. If the judge stops the examination in order to implement diversion, the judge will not make a conviction. ${ }^{28}$

The objectives of diversion according to the provisions of Article 6 of Act No. 11 of 2012 are:

- Achieve peace between victims and children;

- Resolving children's cases outside the judicial process;

- Prevent children from being deprived of liberty;

- Encourage the community to participate; and

- Instilling a sense of responsibility to children.

Conflict situations between the perpetrator of the crime and the victim and/or his family can be eliminated or at least reduced, when the hurt feelings of the victim and/or his family created by the crime maker can be eliminated by rebuilding good relations, one of which is in the form of the victim receiving restitution from the crime maker. . ${ }^{29}$

Thus, the program of providing restitution to victims, conflicts are eliminated and the parties have reconciled, so as to reassure and restore good relations between the child offender and the victim and/or his family.

Diversion is a system that provides a better opportunity for perpetrators of minor crimes who are carrying out their actions for the first time, compared to the provision of punishment in the form of imprisonment. With this program, the community can also play a role in monitoring the self-development of the perpetrator and re-accepting him as a good citizen, on the other hand the government is also more flexible and effective in providing compensation and repairs to damage caused by his actions. the perpetrator. $^{30}$

The implementation of diversion is carried out voluntarily by the parties involved, so that diversion avoids using the element of coercion to make people obey the law. This means that the principle of justice is upheld in law enforcement, including when the diversion principles are applied. Justice in the concept of diversion is an effort to place the value of honesty, equal treatment of all people and demands that officers do not differentiate between people with different actions. The implementation of diversion aims at realizing justice and enforcing the law properly by minimizing criminal coercion. $^{31}$

Settlement through diversion in the juvenile criminal justice process is regulated in Article 8 of Act No. 11 of 2012. Article 8 of Act No. 11 of 2012 states that:

- The diversion process is carried out through deliberation involving children and their parents/guardians, victims and/or their parents/guardians, community counselors, and professional social workers based on a restorative justice approach;

- If necessary, the deliberation as referred to in paragraph (1) may involve social welfare workers and/or the community;

- The diversion process must pay attention to:

\footnotetext{
28 Ibid., p. 143.

29 Ibid.

${ }^{30}$ Setya Wahyudi, op.cit., p. 58-59.

${ }^{31}$ Marlina, loc.cit., p. 22.
} 
- The interests of the victim;

- Children's welfare and responsibility;

- Avoidance of negative stigma;

- Retaliation avoidance;

- Community harmony; and

- Appropriateness, decency and public order.

The application of diversion in the settlement of every case where the perpetrators of a criminal act are children is an obligation for law enforcement officials. The handling of juvenile criminal cases by prioritizing diversion as an obligation is regulated in Article 5 paragraph (1) and Article 7 of Act No. 11 of 2012. In Article 5 paragraph (1) of Act No. 11 of 2012 it is stated that: "The Criminal Justice System Children must prioritize a restorative justice approach ". Restorative justice in question is the obligation to carry out diversion, while Article 7 of Act No. 11 of 2012 states that:

- At the level of investigation, prosecution and examination of children's cases in district courts, it is obligatory to seek diversion;

- Diversion as referred to in paragraph (1) shall be implemented in the event of a criminal act that has committed:

- By imprisonment of under 7 (seven) years, shall be punished; and

- Not a repeat of a criminal act.

As stated, diversion is carried out at the level of investigation, prosecution and examination of children's cases in district courts, so that in the criminal justice system it is mandatory to resolve through diversion. If there is no diversion, it can be invalidated by law. Diversion in the juvenile criminal justice system is a form of legal protection for children who commit criminal acts. The provision of diversion is applied to criminal offenses with a penalty of less than seven years and does not constitute a repetition of a criminal act.

\section{Closing}

Diversion in law enforcement of child criminal acts in the juvenile criminal justice system is persuasive action or an approach that aims to invite the public to obey and enforce the law while still considering the sense of justice as a top priority in addition to providing opportunities for perpetrators to improve themselves. Settlement through diversion in the juvenile criminal justice process is regulated in Article 8 of Act No. 11 of 2012, which is carried out through deliberation involving the child and his/her parents/guardians, the victim and/or his/her parents/guardians, social advisors, and the diversion provisions. is committed against a criminal act which carries a sentence of less than seven years and does not constitute a repetition of a criminal act. Diversion can be an effort for criminal offenders to correct their mistakes, and diversion can be carried out for minor crimes to reduce the burden on correctional institutions and can reduce interactions between prisoners to obtain criminal knowledge from other prisoners.

\section{References}




\section{Journals}

[1] Aan Hardiansyah, Akhmad Khisni, and Jawade Hafidz, March 2018, Violence in the Teaching and Learning Process Viewed from the Perspective of Criminal Law and Act No. 14 of 2005 Regarding Teachers and Lecturers, Jurnal Daulat Hukum, Vol. 1. No. 1, Faculty of Law, Universitas Islam Sultan Agung, Semarang, url: http: //jurnal.unissula. ac.id/index.php/RH/article/view/2622/1972.

[2] Farhan Munirus Su'aidi and Abdullah Arief Cholil, December 2019, Law Protection on Wife Whose The Claims Fall Due To Husband Refuse His Recompensation On Implementing Of Divorce Pledge, Jurnal Daulat Hukum, Vol. 2 No. 4, Faculty of Law, Universitas Islam Sultan Agung, Semarang, url: http://jurnal.unissula.ac.id/index.php/ RH/article/view/8367/3897.

[3] Fiska Ananda, March 2018, Application of Diversion as Efforts to Protect the Law Against Child Perpetrators of Crime, Jurnal Daulat Hukum, Vol. 1. No. 1, Faculty of Law, Universitas Islam Sultan Agung, Semarang, url: http://jurnal.unissula.ac.id/index.php/RH/arti cle/view/2566/1923.

[4] Hengki Irawan, Sri Endah Wahyuningsih, and Jawade Hafidz, December 2019, Legal Protection For Victims Of Traffic Violations That Lead To Death (Case Study On Police Traffic of Rembang), Jurnal Daulat Hukum, Vol. 2 No. 4, Faculty of Law, Universitas Islam Sultan Agung, Semarang, url: http://jurnal.unissula.ac.id/index.php/RH/arti cle/view/8349/3869.

[5] Rendy Surya Aditama, Umar Ma'ruf, and Munsharif Abdul Chalim, March 2018, Criminal Law Policy Against Children as Perpetrators of Psychotropic Crimes at the Magelang Resort Police, Jurnal Daulat Hukum, Vol. 1. No. 1, Faculty of Law, Universitas Islam Sultan Agung, Semarang url: http://jurnal.unissula.ac.id/index.php/ RH/article/view/2625/1974.

\section{Books}

[1] Latif, Abdul. (2014). Hukum Administrasi Dalam Praktik Tindak Pidana Korupsi, First Edition. Jakarta: Kencana Prenada Media

[2] Sinaga, Dahlan. (2017). Penegakan Hukum Dengan Pendekatan Diversi (Perspektif Teori Keadilan Bermartabat), First Edition. Yogyakarta: Nusa Media

[3] Setiadi, Edi and Kristian. (2017). Peradilan Pidana Terpadu Dan Sistem Penegakan Hukum Di Indonesia, First Edition. Jakarta: Kencana Prenada Media Group

[4] Setiadi, Edi and Rena Yulia. (2010). Hukum Pidana Ekonomi. Yogyakarta: Graha Ilmu

[5] Arsyad, Jawade Hafidz and Dian Karisma. (2018). Sentralisasi Birokrasi Pengadaan Barang \& Jasa Pemerintah. Jakarta: Sinar Grafika

[6] Ibrahim, Jhonny. (2011). Teori dan Metodologi Penelitian Hukum Normatif. Malang: Bayumedia

[7] Jamil, M. Nasir. (2013). Anak Bukan Untuk Dihukum, Catatan Pembahasan UndangUndang Sistem Peradilan Pidana Anak (UU SPPA). Jakarta: Sinar Grafika

[8] Gultom, Maidin. (2010). Perlindungan Hukum Terhadap Anak, Second Edition. Bandung: Refika Aditama

[9] Marlina. (2012). Peradilan Pidana Anak Di Indonesia, Pengembangan Konsep Diversi dan Restorative Justice, Second Edition. Bandung: Refika Aditama

[10] Effendy, Marwan. (2012). Diskresi, Penemuan Hukum, Korporasi \& Tax Amnesty Dalam Penegakan Hukum, First Edition. Jakarta: Referensi 
[11] Mukti Fajar ND and Yulianto Achmad. (2010). Dualisme Penelitian Hukum Normatif dan Empiris. Yogyakarta: Pustaka Pelajar

[12] Sinamo, Nomensen. (2014). Hukum Tata Negara Indonesia, Third Edition. Jakarta: Permata Aksara

[13] Wahyudi, Setya. (2011). Implementasi Ide Diversi Dalam Pembaruan Sistem Peradilan Pidana Anak Di Indonesia, First Edition. Yogyakarta: Genta Publishing

[14] Soeratno and Lincolin Arsyad. (2003). Metodologi Penelitian Untuk Ekonomi Dan Bisnis. Yogyakarta: UPP AMP YKPN

[15] Parera, Theodorus Yosep. (2016). Advokat dan Penegakan Hukum, First Edition. Yogyakarta: Genta Press

[16] Setiady, Tolib. (2010). Pokok-Pokok Hukum Panitensier Indonesia. Bandung: Alfabeta

[17] Wagiati Soetedjo and Melani. (2017). Hukum Pidana Anak, Fifth Edition. Bandung: Refika Aditama 